\title{
Mortality among long-term employees of an Ontario asbestos-cement factory
}

\author{
M M FINKELSTEIN \\ From the Special Studies and Services Branch, Ontario Ministry of Labour, Toronto, Ontario M7A 1T7, \\ Canada
}

ABSTRACT Mortality was studied among a group of 328 employees of an Ontario asbestos-cement factory who had been hired before 1960 and who had been employed for a minimum of nine years. The group of 87 men who had worked in the rock wool/fibre glass operations, or who had been otherwise minimally exposed to asbestos, had mortality rates similar to those of the general Ontario population, while the group of asbestos-exposed employees had all-cause mortality rates double those of the Ontario population, mortality rates due to malignancies five times higher than expected, and deaths attributed to lung cancer eight times more frequent than expected. According to the best evidence available, 10 of 58 deaths among the production workers were due to malignant mesothelioma and 20 to lung cancer. The men dying of mesothelioma were younger than the men dying of lung cancer with mean ages at death of 51 and 64 years respectively. An exposure model was constructed on the basis of the available air sampling data, and individual exposure histories were calculated. These exposure histories were used to investigate the exposure-response relationships for asbestos-associated malignancies.

The manufacture of asbestos-cement products consumes a sizable proportion of current asbestos use; in the United Kingdom in 1976, for example, this proportion was about $35 \%$.' There have been several reports of the health experience of workers in the asbestos-cement industry. Scansetti et al, ' Weill et al, ${ }^{3}$ Segarra et al, ${ }^{4}$ and Finkelstein all found that asbestos-cement workers, exposed to historical dust conditions, were at risk of developing asbestosis. Weill $e t$ $a l^{\circ}$ found no excess mortality, overall, in any category of dust exposure and increased rates of lung cancer only among workers with the highest cumulative exposures. Clemmesen and Hjalgrim-Jensen? reported three deaths from mesothelioma and increased rates of lung cancer among 5686 employees of a Danish asbestos-cement factory. Henderson and Enterline ${ }^{x}$ found increased rates of respiratory cancer among retirees of an American asbestos company, many of whom had been employed in the production of asbestos-cement.

We report a study of mortality among long-term employees of an Ontario asbestos-cement factory; these men were found to be at substantially increased risk of death from lung cancer and mesothelioma.

Received 13 January 1982

Accepted 14 June 1982

\section{Methods}

THE FACTORY

The factory began production in 1948 manufacturing asbestos-cement pipe in one building and rock-wool insulation in another. In a third building asbestoscement board was produced from 1955 to 1970 and in 1960 the manufacture of asbestos insulation materials was added. In both the pipe and board operations raw materials included cement, silica, and asbestos. Bagged asbestos fibre was unloaded from boxcars, transported to storage and then to the plant, where it was dumped into "willows" machines for opening of the fibres. Bulk silica was unloaded from hopper cars and transported by conveyor to storage bins.

In the pipe process both chrysotile and crocidolite asbestos were generally used in each batch. The asbestos, silica, and cement were blended in a dry mixer and added to water to form a slurry; the pipe was formed on smooth steel mandrels rotating in this slurry. The moist pipe was cured before being taken to the finishing end of the shop where it was machined and cut to specifications. In the asbestoscement board operation chrysotile asbestos was the only type of asbestos used.

There was little change in formula or process over the history of the plant, although improvements in 138 
ventilation and work practices led to an appreciable lowering of dust concentrations in the factory air and worker breathing zones.

\section{EXPOSURES}

Air sampling had been carried out at the plant by government, company, and insurance hygienists, and these data were used to classify the men according to the estimated cumulative exposures. The model used and the difficulties associated with it have been described elsewhere. ${ }^{5}$ To summarise briefly, exposure assignments were based on the results of personal membrane filter sampling performed by the company starting in late 1969 . Exposures were assumed to have been unchanged from 1962 to 1970 , to have been $30 \%$ higher from 1955 to 1961 , and to have been twice as high during 1948-54. The assumptions were weakly supported by the results of impinger area sampling performed in 1949, 1954, 1955, 1957, and semi-annually during the 1960s. Examples of exposure assignments for the years 1949, 1969, and 1979 are: for the willows operators- $40,20,0.2$ fibres $/ \mathrm{ml}(\mathrm{f} / \mathrm{ml})$; for the forming machine operators$16,8,0.5 \mathrm{f} / \mathrm{ml}$; for the lathe operators- $8,4,0.3 \mathrm{f} / \mathrm{ml}$. The extrapolations made to arrive at the exposure estimates are quite crude, but the cumulative exposures calculated from the model are judged to be accurate to within a factor of three or five.

\section{THE COHORT}

The company provided a list of all hourly and salaried employees who had worked at the plant. Because of the long latency of asbestos-related diseases and difficulties in tracing short-term employees, the group selected consisted of the 339 men hired before 1960 who had been employed by the company for at least nine years. These men were divided among three sub-groups: 186 production workers exposed to asbestos dust for at least 12 months in either the pipe or board shops, 55 maintenance workers, and 87 men employed in the rock wool/fibre glass operations or who were otherwise minimally exposed to asbestos dust. An additional 11 men (3.2\% of the total) could not be properly classified from their work histories and were excluded from the analysis.

\section{MEASURES OF EXPOSURE}

The company maintains excellent employment records that contain a chronological listing of job assignments for each employee. These records were matched with the exposure estimates to provide estimates of the annual exposures of each production worker; it was not thought possible to estimate exposures for the maintenance men. For those jobs for which baseline measurements from 1969 to 1970 were not available, estimates were based on a combination of measurements from other jobs.

In an earlier study of asbestosis among the employees of this factory ${ }^{5}$ we selected as the exposure parameter the cumulative exposure during the 18 years from first exposure, and it was decided to use the same parameter in this analysis. For men employed for under 18 years this parameter is equal to their entire cumulative exposure; for men exposed for over 18 years exposures accumulated after the eighteenth year made no contribution to the exposure parameter-generally these additional exposures were less than $10 \%$ of the 18 -year totals.

The 186 men in the production group were ranked in terms of their 18-year cumulative exposures and divided into three groups of 62 men each on the basis of this ranking (table 1, lower part) .

\section{FOLLOW-UP}

The men were followed up until 31 October 1980 by a local trace, supplemented by a mortality search performed by Statistics Canada. Five of 186 production workers $(2.7 \%)$ were untraced as were three of the 55 maintenance workers $(5.5 \%)$ and five of the 87 unexposed or minimally exposed workers $(5 \cdot 7 \%)$.

Table 1 Mortality rates in the interval 20-33 years from first exposure and estimated dust exposure of three groups of workers. (Number of deaths in parentheses)

\begin{tabular}{|c|c|c|c|c|}
\hline \multirow[t]{3}{*}{ Cause } & \multicolumn{4}{|c|}{ Exposure group } \\
\hline & Group $A$ & Group B & Group C & Ontario men ${ }^{\dagger}$ \\
\hline & \multicolumn{4}{|c|}{ Rates (per 1000 man-years)* } \\
\hline $\begin{array}{l}\text { Mesothelioma } \\
\text { Lung cancer } \\
\text { Gastrointestinal cancer } \\
\text { All malignancies } \\
\text { Mesothelioma crude rates } \\
\text { Estimated exposure range }(\mathrm{f}-\mathrm{y} / \mathrm{ml}) \\
\text { Estimated mean exposure }(\mathrm{f}-\mathrm{y} / \mathrm{ml}) \\
\text { Standard deviation }\end{array}$ & $\begin{array}{l}1 \cdot 9(1) \\
13 \cdot 6(5) \\
0(0) \\
17 \cdot 3(7) \\
2 \cdot 5(1) \\
8-69 \\
44 \\
19 \cdot 4\end{array}$ & $\begin{array}{l}4 \cdot 9 \quad(2) \\
26 \cdot 1 \quad 7) \\
2 \cdot 5 \quad(1) \\
35 \cdot 9(11) \\
4 \cdot 6(2) \\
69-121 \\
92 \\
15 \cdot 8\end{array}$ & $\begin{array}{l}11 \cdot 9(6) \\
11 \cdot 9(6) \\
6 \cdot 0(3) \\
31 \cdot 8(16) \\
11 \cdot 9(6) \\
122-420 \\
180 \\
57\end{array}$ & $\begin{array}{l}-1 \cdot 6 \\
0 \cdot 6 \\
4 \cdot 7 \\
-\end{array}$ \\
\hline
\end{tabular}

${ }^{*}$ Standardised to age distribution of group $\mathrm{C}$.

†Based on Ontario vital statistics 1970-4. 
Table 2 Mortality among the factory workers compared with the population of Ontario

\begin{tabular}{|c|c|c|c|c|c|c|c|c|c|c|c|c|c|}
\hline \multirow[t]{3}{*}{ Cause } & \multirow[t]{3}{*}{ Group } & \multicolumn{12}{|c|}{ Years since first exposure } \\
\hline & & \multicolumn{3}{|c|}{$15-19$} & \multicolumn{3}{|c|}{$20-24$} & \multicolumn{3}{|c|}{$25-33$} & \multicolumn{3}{|c|}{ Total: $20-33$} \\
\hline & & Obs & $\operatorname{Exp}$ & $O / E$ & Obs & $\operatorname{Exp}$ & $O / E$ & Obs & $\operatorname{Exp}$ & $O / E$ & Obs & $\operatorname{Exp}$ & $O / E$ \\
\hline All causes & $\begin{array}{l}\mathbf{P} \\
\underset{C}{P}\end{array}+\mathbf{M}$ & $\begin{array}{r}8 \\
11 \\
7\end{array}$ & $\begin{array}{r}8.9 \\
11.9 \\
5.0\end{array}$ & $\begin{array}{l}1 \\
1 \\
1 \cdot 4\end{array}$ & $\begin{array}{r}16 \\
22 \\
7\end{array}$ & $\begin{array}{r}11 \cdot 8 \\
15 \cdot 5 \\
5 \cdot 9\end{array}$ & $\begin{array}{l}1 \cdot 4 \\
1.4 \\
1 \cdot 2\end{array}$ & $\begin{array}{r}34 \\
39 \\
7\end{array}$ & $\begin{array}{r}11 \cdot 6 \\
15 \cdot 1 \\
7 \cdot 4\end{array}$ & $\begin{array}{l}2 \cdot 9 \\
2 \cdot 6 \\
1\end{array}$ & $\begin{array}{l}50 \\
61 \\
14\end{array}$ & $\begin{array}{l}23 \cdot 4 \\
30 \cdot 6 \\
13 \cdot 3\end{array}$ & $\begin{array}{l}2 \cdot 1 \\
2 \cdot 0 \\
1\end{array}$ \\
\hline $\begin{array}{l}\text { All malignancies } \\
\text { ICD: 140-209 }\end{array}$ & $\underset{\mathrm{C}}{\mathrm{P}}+\mathrm{M}$ & $\begin{array}{l}2 \\
2 \\
3\end{array}$ & $\begin{array}{l}1.9 \\
2.5 \\
1.1\end{array}$ & $\begin{array}{l}1 \\
1 \\
2 \cdot 7\end{array}$ & $\begin{array}{r}9 \\
11 \\
3\end{array}$ & $\begin{array}{l}2.8 \\
3.7 \\
1.4\end{array}$ & $\begin{array}{l}3 \cdot 2 \\
3 \cdot 0 \\
2 \cdot 1\end{array}$ & $\begin{array}{r}20 \\
23 \\
1\end{array}$ & $\begin{array}{l}2.9 \\
3.7 \\
1.8\end{array}$ & $\begin{array}{l}6 \cdot 9 \\
6 \cdot 2 \\
1\end{array}$ & $\begin{array}{r}29 \\
34 \\
4\end{array}$ & $\begin{array}{l}5 \cdot 7 \\
7 \cdot 4 \\
3 \cdot 2\end{array}$ & $\begin{array}{l}5 \cdot 1 \\
4 \cdot 6 \\
1\end{array}$ \\
\hline $\begin{array}{l}\text { Lung cancer } \\
\text { ICD: } 162\end{array}$ & $\begin{array}{l}\stackrel{P}{P} \\
\mathbf{C}\end{array}$ & $\begin{array}{l}1 \\
1 \\
0\end{array}$ & $\begin{array}{l}0 \cdot 6 \\
0 \cdot 8 \\
0 \cdot 3\end{array}$ & $\begin{array}{l}1 \\
1 \\
0\end{array}$ & $\begin{array}{l}6 \\
7 \\
0\end{array}$ & $\begin{array}{l}1.0 \\
1.2 \\
0.5\end{array}$ & $\begin{array}{l}6 \cdot 0 \\
5 \cdot 8 \\
0\end{array}$ & $\begin{array}{r}11 \\
12 \\
1\end{array}$ & $\begin{array}{l}1.0 \\
1.3 \\
0.6\end{array}$ & $\begin{array}{c}11 \cdot 0 \\
9 \cdot 2 \\
1\end{array}$ & $\begin{array}{r}17 \\
19 \\
1\end{array}$ & $\begin{array}{l}2 \cdot 0 \\
2 \cdot 5 \\
1 \cdot 1\end{array}$ & $\begin{array}{l}8 \cdot 5 \\
7 \cdot 6 \\
1\end{array}$ \\
\hline $\begin{array}{l}\text { Mesothelioma } \\
\text { ICD: } 163,158,228\end{array}$ & $\mathbf{P}$ & 1 & - & - & 2 & - & - & 4 & - & - & 6 & - & - \\
\hline $\begin{array}{l}\text { Gastrointestinal cancer } \\
\text { ICD: } 150-154\end{array}$ & $\begin{array}{l}\stackrel{P}{P} \\
\mathbf{C}\end{array}$ & $\begin{array}{l}0 \\
0 \\
1\end{array}$ & $\begin{array}{l}0 \cdot 5 \\
0 \cdot 7 \\
0 \cdot 3\end{array}$ & $\begin{array}{l}0 \\
0 \\
1\end{array}$ & $\begin{array}{l}1 \\
1 \\
1\end{array}$ & $\begin{array}{l}0.7 \\
0.9 \\
0 \cdot 3\end{array}$ & $\begin{array}{l}1 \\
1 \\
1\end{array}$ & $\begin{array}{l}2 \\
3 \\
0\end{array}$ & $\begin{array}{l}0.7 \\
0.9 \\
0.4\end{array}$ & $\begin{array}{l}2 \cdot 9 \\
3 \cdot 3 \\
0\end{array}$ & $\begin{array}{l}3 \\
4 \\
1\end{array}$ & $\begin{array}{l}1.4 \\
1.8 \\
0.7\end{array}$ & $\begin{array}{l}2 \cdot 1 \\
2 \cdot 2 \\
1\end{array}$ \\
\hline $\begin{array}{l}\text { Non-malignant } \\
\text { respiratory disease } \\
\text { ICD: } 460-519\end{array}$ & $\underset{\mathrm{C}}{\mathrm{P}}+\mathrm{M}$ & $\begin{array}{l}1 \\
1 \\
0\end{array}$ & $\begin{array}{l}0 \cdot 4 \\
0 \cdot 6 \\
0 \cdot 3\end{array}$ & $\begin{array}{l}1 \\
1 \\
0\end{array}$ & $\begin{array}{l}1 \\
3 \\
0\end{array}$ & $\begin{array}{l}0.7 \\
0.9 \\
0 \cdot 4\end{array}$ & $\begin{array}{l}1 \\
3 \cdot 3 \\
0\end{array}$ & $\begin{array}{l}3 \\
4 \\
1\end{array}$ & $\begin{array}{l}0 \cdot 8 \\
1 \cdot 0 \\
0 \cdot 5\end{array}$ & $\begin{array}{l}3 \cdot 8 \\
4 \cdot 0 \\
1\end{array}$ & $\begin{array}{l}4 \\
7 \\
1\end{array}$ & $\begin{array}{l}1.5 \\
1.9 \\
0.9\end{array}$ & $\begin{array}{l}2 \cdot 7 \\
3 \cdot 7 \\
1\end{array}$ \\
\hline $\begin{array}{l}\text { Ischaemic } \\
\text { heart disease } \\
\text { ICD: } 410-414\end{array}$ & $\begin{array}{l}\mathrm{P} \\
\mathrm{C}\end{array}+\mathrm{M}$ & $\begin{array}{l}4 \\
7 \\
3\end{array}$ & $\begin{array}{l}3 \cdot 9 \\
4 \cdot 9 \\
2 \cdot 1\end{array}$ & $\begin{array}{l}1 \\
1 \cdot 4 \\
1\end{array}$ & $\begin{array}{l}2 \\
3 \\
1\end{array}$ & $\begin{array}{l}4 \cdot 7 \\
6 \cdot 2 \\
2 \cdot 4\end{array}$ & $\begin{array}{l}0 \cdot 4 \\
0 \cdot 5 \\
0 \cdot 4\end{array}$ & $\begin{array}{l}5 \\
6 \\
2\end{array}$ & $\begin{array}{l}4 \cdot 6 \\
6 \cdot 0 \\
2 \cdot 9\end{array}$ & $\begin{array}{l}1 \\
1 \\
1\end{array}$ & $\begin{array}{l}7 \\
9 \\
3\end{array}$ & $\begin{array}{r}9 \cdot 3 \\
12 \cdot 2 \\
5 \cdot 3\end{array}$ & $\begin{array}{l}0.8 \\
0.7 \\
0.6\end{array}$ \\
\hline
\end{tabular}

$\mathrm{P}=$ Production workers. $\mathrm{M}=$ Maintenance workers. $\mathrm{C}=$ Unexposed workers.

For the purposes of analysis it was assumed that all of the untraced men were still alive. This assumption has little effect on the number of man-years of observation, but could lead to an underestimate of the standardised mortality ratios (SMRs).

For all men who had died the official death certificate codings were obtained. For some we were also able to obtain clinical, pathological, and necropsy reports; this additional information was available for 44 of the 58 deaths among the production workers and has been used for the calculations concerning internal comparisons.

Information on smoking was obtained for about $70 \%$ of the men by personal contact, from an examination of the clinical records of the Occupational Chest Disease Service of the Ontario Ministry of Labour, and from doctors' reports.

\section{CALCULATIONS}

Mortality among the factory workers was compared with that predicted from Ontario age and calendar specific mortality rates by the man-years method. For comparison against this external standard the causes of death were classified according to the official death certificate codings. For all comparisons internal to the cohort the "best evidence" about the cause of death was used. For the exposure-response calculations, mortality rates in each of the exposure categories $(\mathrm{A}, \mathrm{B}$, and $\mathrm{C})$ were calculated for the interval 20-33 years from first exposure. As the age distributions were somewhat different in each of the categories, the mortality rates were standardised to the age distribution of group C.

\section{Results}

\section{EXTERNAL COMPARISONS}

The mortality observed among the employees was compared with the mortality predicted from Ontario population rates (table 2 ). To increase the man-years of observation in each cell, the second group, listed as $\mathbf{P}+\mathbf{M}$ in the table, combines the experience of the production and maintenance employees, all of whom were exposed to asbestos. The mean age at the start of exposure (or of employment for the non-exposed) was similar for all three groups-about 33 years.

\section{INTERNAL COMPARISONS}

These comparisons are based on the best evidence classification.

\section{Malignant mesothelioma}

There were 10 deaths from malignant mesothelioma ( 5 pleural, 5 peritoneal) among the 58 deaths occurring in the production workers-a proportional mortality of $17 \%$ (table 3 ). In addition, one of the maintenance workers died of a pleural mesothelioma. All of these men had been exposed to both 
Table 3 Mortality rates from mesothelioma and lung cancer among the production workers (based on best evidence)

\begin{tabular}{|c|c|c|c|c|c|c|}
\hline \multirow{2}{*}{\multicolumn{2}{|c|}{$\begin{array}{l}\text { Time since first exposure } \\
\text { (years) }\end{array}$}} & \multicolumn{5}{|l|}{ Age } \\
\hline & & \multirow{2}{*}{$\begin{array}{c}35-44 \\
2 \\
413 \\
4 \cdot 8 \\
1 \\
124 \\
8 \cdot 0\end{array}$} & \multirow{2}{*}{$\begin{array}{c}45-54 \\
5 \\
865 \\
5 \cdot 8 \\
5 \\
493 \\
10 \cdot 1\end{array}$} & \multirow{2}{*}{$\begin{array}{c}55-64 \\
3 \\
694 \\
4 \cdot 3 \\
3 \\
485 \\
6 \cdot 2\end{array}$} & \multirow{2}{*}{$\begin{array}{r}65-75 \\
0 \\
244 \\
0 \\
0 \\
213 \\
0\end{array}$} & \multirow{2}{*}{$\begin{array}{c}75 \text { or more } \\
0 \\
21 \cdot 5 \\
0 \\
0 \\
21 \cdot 5 \\
0\end{array}$} \\
\hline $\begin{array}{l}\text { Mesothelioma } \\
15-33 \\
20-33\end{array}$ & $\begin{array}{l}\text { No of cases } \\
\text { Man-years } \\
\text { Rate (per } 1000 \text { man-years) } \\
\text { No of cases } \\
\text { Man-years } \\
\text { Rate (per } 1000 \text { man-years) }\end{array}$ & & & & & \\
\hline \multirow[t]{2}{*}{$\begin{array}{l}\text { Lung cancer } \\
15-33 \\
20-33\end{array}$} & $\begin{array}{l}\text { No of cases } \\
\text { Man-years } \\
\text { Rate (per } 1000 \text { man-years) } \\
\text { No of cases } \\
\text { Man-years } \\
\text { Rate (per } 1000 \text { man-years) }\end{array}$ & $\begin{array}{r}0 \\
413 \\
0 \\
0 \\
124 \\
0\end{array}$ & $\begin{array}{r}0 \\
865 \\
0 \\
0 \\
493 \\
0\end{array}$ & $\begin{array}{c}13 \\
694 \\
18 \cdot 7 \\
11 \\
485 \\
22 \cdot 7\end{array}$ & $\begin{array}{c}6 \\
244 \\
24 \cdot 6 \\
6 \\
213 \\
28 \cdot 2\end{array}$ & $\begin{array}{c}1 \\
21 \cdot 5 \\
46 \cdot 5 \\
1 \\
21 \cdot 5 \\
46 \cdot 5\end{array}$ \\
\hline & $\begin{array}{l}\text { Ontario rates (based on } \\
\text { vital statistics } 1970-4 \text { ) } \\
\text { (per } 1000 \text { man-years) }\end{array}$ & $0 \cdot 1$ & 0.5 & 1.7 & $3 \cdot 5$ & $3 \cdot 8$ \\
\hline
\end{tabular}

chrysotile and crocidolite in the pipe plant. Six of them worked at the pipe-rolling machines, two had worked at mixing operations, one had been a lathe operator, and one man a lathe operator and then shift foreman. Ten of these 11 cases have undergone pathological review and the diagnoses have been confirmed. The mean age at death of these 10 men was 51 years and none was over 60 (table 4 ).

The mortality rates for mesothelioma among the production workers are displayed in table 3 as a function of age. Table 5 gives the crude incidence rates for mesothelioma among all the asbestosexposed employees, as related to the time interval since first exposure. Peto et $a l^{\prime}$ have suggested that the incidence of mesothelioma follows a power function relationship with time. Our data are consistent with this suggestion, with an exponent value of between three and four.

Information on smoking was available for nine of the 11 men who died of mesothelioma: two had never smoked, two had ceased for 10 or more years, and five were smokers.

\section{Lung cancer}

There were 20 deaths from lung cancer among the 58 deaths in the production workers-a proportional mortality of $34 \%$. We have pathological information about 17 of these 20 cases; four were adenocarcinomas, eight were squamous, four were small cell undifferentiated, and one was a large cell undifferentiated tumour. As a group, these men were first exposed to asbestos in this plant at an older age, and they died later in life than the men dying of mesothelioma (table 4).

Table 3 presents the lung cancer mortality rates among the production workers. At the foot of the table are listed, for illustrative purposes, the 1970-4 rates for lung cancer among men in Ontario. These
Table 4 Some characteristics of the cases of mesothelioma and lung cancer. (Classified according to best evidence)

\begin{tabular}{llll}
\hline & Mean & Range & $\begin{array}{c}\text { Standard } \\
\text { deviation }\end{array}$ \\
\hline Mesothelioma $(\mathrm{n}=10)$ & & & \\
$\quad$ Age at first exposure & 25 & $19-32$ & $4 \cdot 3$ \\
Age at death & 51 & $42-57$ & $5 \cdot 4$ \\
Latency (years)* & 25 & $17-30$ & $3 \cdot 8$ \\
Lung cancers (n= 20) & 39 & $31-52$ & $6 \cdot 4$ \\
$\quad$ Age at first exposure & 64 & $55-78$ & $5 \cdot 9$ \\
Age at death & 25 & $17-29$ & $3 \cdot 6$ \\
Latency (years)* & & & \\
\hline
\end{tabular}

${ }^{*}$ Latency is the interval from first exposure to death.

Table 5 Incidence rates of mesothelioma among the production and maintenance workers exposed to asbestos

\begin{tabular}{lrrrr}
\hline & \multicolumn{4}{c}{ Time since first exposure (years) } \\
\cline { 2 - 5 } & $15-19$ & $20-24$ & $25-29$ & $30-34$ \\
\hline $\begin{array}{l}\text { No of cases } \\
\begin{array}{l}\text { Man-years of risk } \\
\text { Incidence rate }\end{array}\end{array}$ & 1182 & 1061 & 555 & 104 \\
(per 1000 man-years) & 0.8 & 3.7 & 9.0 & 9.6 \\
\hline
\end{tabular}

Ontario rates are based on official death certificate codings; a "best evidence" reclassification would probably result in a small modification of the numbers.

Information on smoking was available for 17 of the 20 men; one claimed never to have smoked, two had stopped at least 10 years before death, and 14 were smokers.

\section{Exposure-response}

Table 1 gives the mortality rates for each of the three exposure groups of production workers, for the interval 20-33 years from first exposure. Although the classification of causes of death is based on best 
evidence, we have also listed, for rough comparison purposes, the 1970-4 mortality rates for men in Ontario, standardised to the age distribution of group $\mathrm{C}$. The number of deaths occurring in each category is very small, making the rates subject to considerable statistical fluctuation. If it is hypothesised that groups $\mathrm{A}, \mathrm{B}$, and $\mathrm{C}$ represent samples from larger groups of workers exposed to similar conditions and that the observed rates form estimates of the means of Poisson sampling distributions, then the $95 \%$ confidence intervals for the mortality rates are: mesothelioma (crude ratesdeaths per 1000 man-years) group A (0.07-13.9), group $B(0 \cdot 5-16 \cdot 7)$, and group $C(4 \cdot 4-26 \cdot 0)$; and lung cancer (rates standardised to group $\mathrm{C}$-deaths per 1000 man-years) group A (5.6-28.8), group B (13.9 $44 \cdot 7)$, and group $C(4 \cdot 4-26 \cdot 0)$.

Three deaths occurring before 20 years from first exposure have been excluded from table 1 . One man who died of mesothelioma had a cumulative exposure that would have placed him in group $B$, while of two men dying of lung cancer one would be in group $A$ and the other in group B.

\section{Discussion}

We investigated mortality among three groups of workers at an Ontario asbestos-cement and mineral fibre factory-that is, 186 production workers, 55 maintenance workers, and a control group of 87 men who were minimally exposed to asbestos. The mean age at entry of these three groups was the same, all were hired before 1960 and were employed for at least nine years, and there is no reason to suspect that the control workers differed in any fundamental way from the exposed workers. The differences in the pattern of mortality may thus be reasonably attributed to the workplace dust exposures, of which asbestos was the major toxic component. The numbers of men were so small that only large increases in risk were detectable - that is, were statistically significant-by epidemiological techniques. With this limitation in mind it was noted that the mortality among the control workers was the same as that expected for the general male population of Ontario, while among the asbestos-exposed employees mortality rates were increased and strongly dependent on the time interval from first exposure. This temporal pattern is consistent with the experience of other cohorts; Selikoff $e t a l,{ }^{10}$ for example, found that excessive mortality from asbestosis, mesothelioma, and lung cancer among North American insulators increased well into the fifth decade from first exposure. The high relative risks observed in the group we studied are, in part, related to the selection process that has excluded shorter-term employees who, presumably, are at lesser risk. The mortality ratios are, however, larger than those found by Weill ${ }^{6}$ for men with 10 or more years of employment in the Louisianna factories; this might be related to differing tracing efficiencies. Work is currently underway to trace workers with one to eight years of employment, and the relative risks in the combined group will probably be lower; clearly, however, employment in the asbestos-cement industry, under historical exposure conditions, has been associated with an adverse health experience.

The men dying of mesothelioma were first exposed to asbestos in this factory at a younger age, and were younger at death than the men dying of lung cancer. In their study of mortality among employees of a New Jersey asbestos factory Henderson and Enterline ${ }^{8}$ found that among 36 deaths due to mesothelioma 29 $(81 \%)$ occurred in men under 65 . Among a group of British dock-yard workers $54 \%$ of 108 deaths from mesothelioma occurred in men under $65 .{ }^{11}$ Elmes and Simpson ${ }^{12}$ report that among 253 cases reviewed by a British mesothelioma panel the mean age at first exposure was 21.5 years and the mean age at death was 50.5 years. In Ontario the Workmen's Compensation Board has accepted 25 fatal claims for mesothelioma; the mean age at death of these men was 56.4 with a standard deviation of 8.6 years. Thus a sizable proportion of deaths due to mesothelioma may occur in men who have not yet reached retirement age. I believe that this factor should be of concern in assessing the risks due to asbestos exposure.

Rates of death from mesothelioma were related to the magnitude of the cumulative exposure; the relation is compatible with a linear function through the origin, but the uncertainties are large. We have learnt of five additional deaths from mesothelioma among former employees who had had under nine years of employment required for entry into this analysis; all these men had been employed in the pipe plant, and all had exposures that would have placed them in group A. Although exposure histories have not yet been computed for all the employees with shorter employment, probably few, if any, would have accumulated sufficient exposure to place them in exposure category $\mathrm{C}$. The meothelioma rates among the long-term employees in group $\mathrm{C}$ are thus likely to be very close to the rates obtained when the calculation is performed for all workers in the factory with exposures of this magnitude.

There is little information with which to compare our quantitative results. Newhouse and Berry ${ }^{13}$ studied mortality among workers in a London textile factory exposed to mixed dusts of asbestos. "Severely" exposed workers were thought to be exposed to asbestos concentrations averaging $20 \mathrm{f} / \mathrm{ml}$ 
or more while workers with "low to moderate" exposures were estimated to have been exposed to concentrations of $2-10 \mathrm{f} / \mathrm{ml}$. With an average followup of 26-28 years, they observed mesothelioma mortality rates of about one per 1000 man-years among severely exposed workers with under two years' exposure as well as among workers with low to moderate exposures who were exposed for over two years. These workers probably had cumulative exposures similar to the men in our group $A$, and the mortality rates are similar.

The lung cancer mortality rates did not increase steadily with increasing estimates of cumulative exposure; in fact, the men in group $\mathrm{C}$ experienced the lowest lung cancer mortality rates of all. Several explanations come immediately to mind. Firstly, it may be that the exposure estimates were so crude that we were unable to classify correctly the men according to cumulative exposure; this may be true, but circumstantial evidence from the asbestosis ${ }^{5}$ and mesothelioma analyses suggests that the classification may have been successful. Secondly, with only 18 deaths from lung cancer to be divided among three groups, there is the problem of fluctuations associated with small numbers. Thirdly, there is the confounding influence of smoking; with the fragmentary smoking histories currently available, there do not appear to be any major differences among the three groups in terms of smoking pattern, but smoking is such an important risk factor that it could be playing a part here.

Peto $^{14}$ studied lung cancer mortality among workers at the English textile factory that has provided the data base for current asbestos hygiene standards. $\mathrm{He}$ had only eight deaths for analysis and was unable to find any relation between cumulative exposure and the risk of lung cancer. Other studies of larger numbers of workers have found relations between exposure and lung cancer rates that appear to be linear. ${ }^{15}$ At this time we are unable to determine the relation between exposure and risk of lung cancer among workers at this factory.

There are only two other cohorts for which lung cancer mortality rates have been studied directly in relation to estimates of fibre exposure rather than total dust exposure. Peto has studied two groups of workers from the English textile factory. Among the 679 men who entered scheduled areas after 1 January 1933 and who had worked for at least 10 years, there were 19 deaths in the period $20-35$ years from first exposure compared with 11 expected. ${ }^{16}$ Average cumulative exposure was estimated to be about 200 $\mathrm{f}-\mathrm{y} / \mathrm{ml}$. In a later analysis ${ }^{14}$ he observed a relative risk of $4.9,20$ or more years after first exposure, among men first employed after 1950. The average cumulative exposure is estimated to have been $200-300 \mathrm{f}-\mathrm{y} / \mathrm{ml}$.
Dement $e a^{17}{ }^{17}$ studied mortality among employees of an American asbestos textile factory. Using a different analytical methodology they calculated an SMR between 500 and 600 for cumulative exposures of $100 \mathrm{f}-\mathrm{y} / \mathrm{ml}$.

In the present study the average cumulative exposure among the production workers is estimated (to within a factor of three to five) to have been about $100 \mathrm{f}-\mathrm{y} / \mathrm{ml}$, and the SMR for the period after 20 years was 850 . Looking at all of these results together, it appears that lung cancer rates, at a cumulative exposure of $100 \mathrm{f}-\mathrm{y} / \mathrm{ml}$, may be raised several-fold.

The mortality rates from gastrointestinal cancer among the men in this study appear to increase with increasing cumulative exposure, but the number of deaths is so small, four, that no firm conclusions may be drawn.

Of the 241 men in the two asbestos-exposed subgroups, $71(29 \%)$ have been certified as suffering a disability due to asbestosis. The high prevalence rate of asbestosis is reflected in increased mortality due to respiratory diseases. The increase in the rates of death from respiratory disease has, so far however, been less than the increase in the rates due to malignancies.

In conclusion, workers at this asbestos-cement factory exposed to historical dust conditions (which were probably not atypical of those elsewhere in the industry) have experienced increased mortality rates from respiratory and malignant diseases. The risks appear to be similar to those observed among asbestos textile workers, and the need for careful attention to controlling exposure in this industry as well is apparent.

I thank Robert Kusiak of the Ontario Ministry of Labour for his help with the computations, Dr W T E McCaughey of the Tumour Reference Centre of the Canadian National Cancer Institute, and Professor A C Ritchie of the University of Toronto for their reviews of the pathological material, and Martha Smith of Statistics Canada for her help with the mortality search.

\section{References}

1 Acheson ED. Gardner M. Ashestos. Final Report of the adisory. committee on asbestos. Vol 2. London: HMSO. 1979:64.

2 Scansetti G. Coscia GC. Pisani W. Rubino GF. Cement. asbestos. and cement-asbestos pneumoconioses. Arch Emiron Health 1975:30:272-5.

${ }^{3}$ Weill H. Waggenspack C. Bailey W. Ziskind M. Rossiter C. Radiographic and psychologic patterns among workers engaged in manufacture of asbestos cement products. JOM 1973:15:248-52.

+ Segarra F. Baselga Monte M. Lopez Ibanez P. Perez Nicholas J. Asbestosis in a Barcelona fibrocement factory. Environ Res 1980:23:292-30). 
5inkelstein M. Asbestosis among long-term employees of an Ontario asbestos-cement factory. Am Rev Respir Dis 1982;125:496-501.

${ }^{6}$ Weill H, Hughes J, Waggenspack C. Influence of dose and fibre type on respiratory malignancy risk in asbestos cement manufacturing. Am Rev Respir Dis 1979;120:345-54.

${ }^{7}$ Clemmeson J, Hjalgrim-Jensen S. Cancer incidence among 5686 asbestos-cement workers followed from 1943 through 1976. Ecotoxicol Environ Safety 1981;5:15-23.

${ }^{x}$ Henderson V, Enterline P. Asbestos exposure: factors associated with excess cancer and respiratory disease mortality. Ann NY Acad Sci 1979;330:117-26.

'Peto J, Seidman H. Selikoff IJ. Mesothelioma mortality in asbestos workers. Br J Cancer 1982;45:124-35.

"Selikoff IJ, Hammond EC. Seidman H. Latency of asbestos disease among insulation workers in the United States and Canada. Cancer 1980:46:2736-40.

"Sheers C, Coles R. Mesothelioma risks in a naval dockyard. Arch
Environ Health 1980:35:276-82.

12 Elmes PC, Simpson MJC. The clinical aspects of mesothelioma. Q J Med 1976:45:427-49.

${ }^{13}$ Newhouse ML. Berry G. Patterns of mortality in asbestos factory workers in London. Ann NY Acad Sci 1979;330:195-203.

${ }^{14}$ Peto $J$. Lung cancer mortality in relation to measured dust levels in an asbestos textile factory. In: Wagner JC. ed. Biological effects of mineral fibres. Lyon: International Agency for Research on Cancer, 1980:829-35. (Scientific Publications No 30.)

${ }^{15}$ McDonald JC, Liddell FDK, Gibbs GW, Eyssen GE, McDonald AD. Dust exposure and mortality in chrysotile mining, 1910 75. Br J Ind Med 1980;37:11-24.

${ }^{16}$ Peto J. The hygiene standard for chrysotile asbestos. Lancet 1978;i:484-9.

${ }^{17}$ Dement JM. Harris RL. Symons MJ. Shy C. Estimates of doseresponse for respiratory cancer among chrysotile asbestos textile workers. Ann Occup Hyg (in press). 